\title{
ANTIHREZA U RIMSKOJ PRAVNOJ DOKTRINI
}

Dr. sc. Ines Matić, univ. spec. crim.* Izv. prof. dr. sc. Anamari Petranović**

\author{
UDK 34(37) \\ https://doi.org/10.30925/zpfsr.39.3.3 \\ Ur.: 19. rujna 2018. \\ Pr.: 12. studenoga 2018. \\ Izvorni znanstveni rad
}

\section{Sažetak}

U radu se obrađuje problem definiranja i sadržaja instituta antihreze s obzirom na dva Marcijanova odlomka sadržana u Digestama (D.13.7.33. i D.20.1.11.1.) i Paulov tekst D.20.2.8., budući da su navedeni tekstovi temeljni i jedini rimski pravni izvori koji izričito tematiziraju ovaj institut. Raščlambom Marcijanovih odlomaka D.13.7.33. i D.20.1.11.1., kao i relevantnih naglasaka pravne doktrine, ističu se osnovna obilježja antihreze te se iznose teorije o pravnoj prirodi toga instituta koje navode na zaključak da antihreza i pactum antichreticum nisu sinonimi, kao što se to najčešće predmnijeva, već dva različita pravna instituta, bitno različitih funkcija, a posljedično is drukčijim sustavom pravne zaštite. Segment rada usmjeren na analizu Paulova teksta D.20.2.8., podastire osnovne značajke prě̌utne antihreze (antichresis tacita) u korelaciji s poimanjem sporazumne antihreze.

Ključne riječi: pactum antichreticum, antihreza, antichresis tacita, rimsko pravo, inominatni ugovori, zalog.

D.50.17.202. Omnis definitio in iure civili periculosa est, parum est enim ut non subverti posset.

\section{1. $U V O D$}

Antihreza (grč. $\alpha v \tau \imath \chi \rho \eta \sigma ı \varsigma)$, od anti - naspram, spram i chrēsis - uporaba, od chrēsthai koristiti, potreba, u doslovnom prijevodu označava davanje zajma naspram/ spram korištenja (stvari založene radi osiguranja povrata zajma). ${ }^{1}$

* Dr. sc. Ines Matić, univ. spec. crim., poslijedoktorandica, Sveučilište u Rijeci, Pravni fakultet; imatic@pravri.hr.

** Dr. sc. Anamari Petranović, izvanredna profesorica Sveučilišta u Rijeci, Pravnog fakulteta; anamari.petranovic@pravri.hr.

1 Prema Glücku, sam izraz antihreza dolazi iz grčkog jezika te nije sigurno znači li utendum dare ili utendum accipere. Međutim, drži sigurnim da riječ antichresis etimološki ima isto značenje kao i mutuus usus, to jest, recipročna uporaba, a označava istodobno pakt kojim se među strankama ugovara recipročna uporaba različitih stvari, pravo koje se stječe tim paktom te i sam objekt tog prava, odnosno stvar koja je na temelju takvog sporazuma stranaka predana 
Hrvatska pravna literatura antihrezu i pactum antichreticum dotiče (Horvat) ${ }^{2}$ ili definira $\left(\right.$ Romac) ${ }^{3}$ u kontekstu prijepornih pitanja u svezi s plodovima u okviru obrazloženja sumarnih značajki sadržaja založnog prava i položaja založnog dužnika i vjerovnika, odnosno značajki prepoznatog ugovora / pravnog posla. U Romčevu Rječniku rimskog prava antihreza je definirana kao „ugovor na temelju kojega je založni vjerovnik mogao upotrebljavati založenu stvar i pobirati plodove."“4 Pojašnjeno je kako je takav pravni posao odstupao od uobičajene zabrane uporabe i korištenja založene stvari kojom bi se činio furtum usus i upravo zbog toga je bio moguć samo kod plodonosnih stvari. Svrha plodova ubranih uz pristanak založnog dužnika bila je namirenje kamata na zajam, a ako se radilo o beskamatnom zajmu, ističe se kako suglasnost založnog dužnika nije bila potrebna već je založni vjerovnik imao pravo ubiranja plodova založene plodonosne stvari do visine uobičajenih kamata u tom mjestu (antichresis tacita). ${ }^{5}$ Ovakva definicija navodi nas na zaključak da je antihreza ugovor neraskidivo povezan s ugovorom o zalogu te da je takav ugovor morao biti izričito zaključen uz kamatni zajam kako bi se vršilo prebijanje vrijednosti plodova s kamatama, dok je prešutna antihreza postojala uz beskamatni zajam jer se smatralo prirodnim da zajmodavac, tj. založni vjerovnik, ima neku korist od danog zajma. S obzirom na to da pod pojmom pactum antichreticum Rječnik rimskog prava upućuje na netom analizirani tekst o antihrezi, ${ }^{6}$ poveznica o nadopuni tumačenja (istog) instituta nameće zaključak da su antihreza i pactum antichreticum sinonimi za jedan te isti pravni institut, posebice i stoga što definiciju vrlo sličnu ili istovjetnu Romčevoj, bilježi i većina romanista. ${ }^{7}$ Provjera navedenoga zaključka ujedno je osnovni cilj ovoga rada.

Kako bi se utvrdilo jesu li antihreza i pactum antichreticum samo dva naziva istog instituta ili ipak dvije zasebne pravne ustanove i time pokušalo razriješiti dvojbe u vezi s rimskim konceptom njihove pravne prirode, analiza će se fokusirati na ključne podatke izvora. Rimski pravni sustav je sustav tužbi i ne temelji se na definiranju (što izrijekom brani poznata maksima Omnis definitio in iure civili periculosa est;

drugoj strani. Iako je ovaj institut svoje ime dobio u pravu stare Grčke, u koje je ušao u 4. st. pr. Kr., raspolaže se dokazima kako su preteče antihreze postojale u pravnim poretcima Babilona, Mezopotamije, u sumerskoj i akadskoj kulturi, gdje je analizom izvora moguće prepoznati temeljne karakteristike antihreze u institutima kao što su tuppi titenūtu i mazzazanatu. Saznanja o njima crpimo iz prijevoda tekstova na glinenim pločicama koje potječu iz 1500. g. pr. Kr., a koji opisuju kako vjerovnik ima pravo plodouživanja na pokretninama i nekretninama koje je dobio u zalog, što mu omogućuje ubirati plodove založene stvari na ime kamata. U rimskom pravu antihreza se pojavljuje krajem klasičnog perioda. Opširnije u Glück, F., Commentario alle Pandette, libro XX, Milano, 1895., str. 373 et seq.

2 Horvat, M., Rimsko pravo, Zagreb, Pravni fakultet, 2007., str. 241.

3 V. bilj. 4.

4 Romac, Ante, Rječnik rimskog prava, Zagreb, Informator, 1975., str. 59.

5 Loc. cit.

6 Ibid., str. 390 .

7 Više u Goebel, R. J., Reconstructing the Roman Law of Real Security, Tulane Law Review, vol. 36, 1961., Mirabelli, G., Dell'anticresi, Napoli, Editore Federico Corrado, 1888., Tedeschi, V., L'Anticresi, Torino, Unione Tipografico - Editrice Torinese,1952., Cohen, B., Antichresis in Jewish and Roman Law, New York, Shulsinger Bros. Inc., 1966., Glück, F., op. cit. 
parum est enim, ut non subverti posset / Javolenus Priscus, D.50.17.202., odnosno što potvrđuje načelo ubi actio ibi ius ${ }^{8}$ kao korelaciju postojanja pravne zaštite putem individualizirane tužbe ${ }^{9}$ i samoga prava $^{10} /$ pravnog odnosa). Upravo na tim postavkama, odnosno polazeći od sustava pravne zaštite, a ne od definicije, gradit će se zaključci kako antihreza i pactum antichreticum nisu jedan te isti institut, što je ujedno osnova za svaku daljnju analizu njihovih (zasebnih) obilježja. ${ }^{11}$

Antihrezu $^{12}$ izričito tematiziraju samo dva fragmenta Marcijanovog teksta iz Digesta ${ }^{13}$ što je jedan od razloga postojanja oprečnih teorija o pravnoj prirodi toga instituta. Dodatno, osim ograničenog broja izvora, poteškoću u istraživanju instituta antihreze stvara i mogućnost postojanja i/ili opseg kompilatorskih preinaka / interpolacija kao gotovo trajni izazov u procjeni izvornosti izvora (Digesta) pa tako i fragmenata podastrijetih u ovom radu.

Detaljna analiza dostupnih vrela, navodi na zaključak kako većina dvojbi o pojmu, genezi i pravnoj prirodi antihreze u rimskom pravu proizlazi primarno iz činjenice da se pojmovi antihreza i pactum antichreticum koriste kao sinonimi, iako je vrlo vjerojatno riječ o dva različita pravna instituta koja odlikuju složene bitne razlike, o kojima će biti riječi u nastavku ovoga rada.

8 O tomu kao i o nepostojanju vice versa opcije v. primjerice Randelzhofer, A., Tomuschat C., (ur.), State responsibility and the individual: reparation in instances of grave violations of human rights, Hague, Kluwer Law International, 1999., str. 234.

9 Fiksna struktura okvira civilnog prava i odnos actio - ius nadopunjava se pretorskim sustavom (... quod praetores introduxerunt adiuvandi vel supplendi vel corrigendi iuris civilis / Papinianus, D.1.1.7.1./). O učešću pretora i oportunom davanju pravne zaštite putem actiones in factum u kontekstu usporedbe obveznog (pret)klasičnog i klasičnog rimskog sustava v. Margetić, L., Rimsko pravo, Rijeka, Pravni fakultet, 1998., str. 226.

10 O konceptu vindikacijske tužbe u usporedbi rimskog i suvremenih stvarnopravnih sustava i okviru primjene pravila ubi actio ibi ius, „što znači da određena osoba uživa pravnu zaštitu samo ako je pravni poredak za takvu situaciju predvidio posebnu tužbu (actio)"v. Petrak, M., Koncepcija generalne vindikacijske tužbe u rimskoj pravnoj tradiciji i de lege ferenda, Zbornik Pravnog fakulteta Sveučilišta u Zagrebu, vol. 63, br. 5-6/2013, str. 1038.

11 Jedan od istaknutijih zagovornika ideje o antihrezi i antihreznom paktu kao različitim institutima je Alegre de Miguel, koji tvrdi da razlog poistovjećivanja ova dva instituta vjerojatno proizlazi iz pogrešne interpretacije grčke riječi chresis koja se može tumačiti kao uporaba, ali isto tako i kao zajam, odnosno uzajamni zajam kada je riječ o antihrezi. „Prava“ antihreza, smatra Alegre de Miguel, kao i Badosa Coll, F., je ugovor koji je uzajamni, recipročni zajam gdje jedna strana prima određeni iznos novca, a druga prima u posjed nekretninu čije plodove ubire dok joj spomenuti iznos novca ne bude vraćen (fructus in vicem usurarum). Vidi Alegre de Miguel, J. D., La anticresis: funcion e finalidad en el Codigo Civil espanol y en el Codigo Civil de Cataluna, Barcelona, ESADE, Facultat de Derecho, Universitat Ramon Llull, 2013., str. 12.

12 Pod tim nazivom u ovome radu podrazumijevamo antihrezu u širem smislu, koja obuhvaća sve ono na što se doktrina referira kao na pactum antichreticum, antihrezu i ugovor o antihrezi, na svim onim mjestima na kojima nije izričito specificirano na koji oblik instituta se misli.

13 Unatoč ovako skromnom broju izvora o institutu antihreze, kazuistička narav rimskih pravnih izvora ne dopušta da se u nedostatku pravne definicije (pojedinog) instituta donese zaključak o njegovoj (i)relevantnosti u stvarnom životu. 


\section{MARC. D.13.7.33.}

Marc. D.13.7.33. Si pecuniam debitor solverit, potest pignorat actione uti ad reciperandam antichresis: nam cum pignus sit, hoc verbo poterit uti.
Nakon što je dužnik isplatio dugovano, može putem actio pigneraticia tražiti povrat stvari dane u antihrezu, jer kada se radi o zalogu može se koristiti ova riječ.

Citirani odlomak D.13.7.33. poima se ishodištem teorije o antihrezi kao vrsti založnog prava. Brojni autori ${ }^{14}$ zaključuju kako je antihreza, koja se spominje u ovom tekstu, zapravo vrsta založnog prava u širem smislu, uz poznatije percipirani ručni zalog (pignus) i ugovorni zalog (hypotheca). Takav zaključak ponajprije temelje na formulaciji nam cum pignus sit (kada se radi o zalogu) koja je izrijekom dio teksta, kao i na činjenici da ovaj odlomak ovlašćuje založnog dužnika na podnošenje tužbe actio pigneraticia, što očigledno upućuje na ovlaštenje koje založni dužnik ima na temelju ugovora o zalogu (contractus pigneraticius).

Održivost ove teorije dovodi u pitanje rimsko načelo numerus clausus stvarnih prava, koje podrazumijeva da su u rimskom pravnom sustavu postojala isključivo sljedeća stvarna prava: dominium/proprietas, servitutes, pignus, hypotheca, emphyteusis i superficies, zbog čega mogućnost svrstavanja antihreze u tu skupinu postaje razborito upitnom. ${ }^{15}$

14 Mirabelli smatra antihrezu jednom vrstom zaloga u širem smislu te je definira kao pravo na plodonosnoj stvari koja se predaje u posjed založnom vjerovniku kako bi on ubirao njezine plodove umjesto kamata na svoje potraživanje. Mirabelli, G., op. cit., str. 7. Iz glose Lotaria: glossa anticresis D.13.7.33. est... anticresis pignus quod sub hoc nomine accepit creditor ut eius usum et fructum pro usuris sibi computet, također se može zaključiti kako je antihreza jedna vrsta zaloga, koji se zasniva izravno i eksplicitno te ju mora prihvatiti vjerovnik koji može koristiti stvar i ubirati njezine plodove na ime kamata, ali nikako ne i za podmirenje same glavnice tražbine. Prema Gualazzini, U., Anticresi, u: Enciclopedia del diritto, Milano, Giuffre, 1967., str. 530. Zaključak o antihrezi kao vrsti zaloga može se iščitati i iz definicije koju daje Cuiacio, a prema kojoj antihreza est species pignoris ita dati ut, donec pecunia solvatur, pignore creditor utatur, fruatur in vicem usurarum. Teoriju o antihrezi kao zalogu podržava i Lauterbach, nazivajući je u svom tekstu antihreznim zalogom porro dividunt doctores pignus in antichreticum... Prema Tedeschi, V., op. cit., str. 5.

15 Potvrda da antihreza nije zalog nalazi se i u Huberovom tekstu: Mihi sic videtur pignus et antichresin esse duas res distinctas, et ex earum coniuctione nasci pignus antichreticum. Ex hoc hypothecariam actionem dari, non est ratio dubitandi. Sed in hoc anticresin solam creditor accepisse proponitur, hoc est, conventio, qua convenit, ut creditor usurarum loco certi praedii fructus percipiat, est celebrata, nihil amplius. De iure pignoris nihil est dictum, et tamen speciali de pignore conventione non constituitur expressum pignus: etsi, quando creditori praedium conceditur ad fructus in vicem usurae inde percipiendos, ea res loco pignoris sit. Verum sine convention de pignore non potest, inquam, actio hypothecaria nasci; ideoque personalis in factum duntaxat, non contra tertium, sed adversus debitorem, qui illam conventionem debito principali, adjecit, datur. De pignoris iure constituto nihil hic est proditum. Nam quod attinet at verba, mutuus pignoris usus, illa non sunt Marciani, sed interpretis, greacam vocem antichresi interpretantis: que tamen nihil, quam mutuum usum denotat. Navedeno podržava $\mathrm{i}$ Von Greve ističući Antichresis differit a pignore, nam si, cui antichresis concessa est, amiserit 
Upravo kritike teorije o antihrezi kao vrsti založnog prava, dovele su do toga da se na temelju istoga teksta izgradi i stajalište o antihrezi kao paktu (pactum antichreticum), koje je ujedno i dominantna teorija o naravi antihreze. S obzirom na to da je u rimskom pravnom sustavu založnom vjerovniku bilo zabranjeno koristiti založenu stvar, ${ }^{16}$ što nedvojbeno potvrđuje Gajev odlomak D.47.2.55.(54).pr. (navodeći si pignore creditor utuatur, furtum tenetur), upravo se u njemu može pronaći ishodište ili motiv za nastanak instituta pactum antichreticum, koji prelaskom iz platforme neformalnih sporazuma za koje je vrijedilo načelo ex nudo pacto nulla actio nascitur, u režimu dodavanja pravnim poslovima bona fidei, najčešće ugovoru o zalogu i radi izbjegavanja navedene zabrane (furtum usus), postaje utuživ, jer je (ugovorna) tužba iz priznatoga kontrakta obuhvaćala i obveze preuzete tim sporazumom (pactum inest contractui).

Analizirajući citirani tekst Marcijanovog odlomka u opisanom kontekstu, može se zaključiti kako predstavlja primjer antihreznog pakta dodanog ugovoru o zalogu, u kojem se izraz antihreza koristi kao termin za založenu stvar te se založnom dužniku omogućuje ostvarivanje zaštite tužbom actio pigneraticia. S obzirom na to da je antihrezni pakt u tom slučaju akcesoran založnopravnom ugovoru kao glavnom ugovoru, to je ujedno definiralo i objekt ovog pakta. Imajući na umu da su, prema Ulpijanu, objekt ručnog zaloga i hipoteke u rimskom pravu mogle biti i pokretnine i nekretnine, jer se razlikovanje ovih instituta ogledalo u činjenici posjedovanja založene stvari, ${ }^{17}$ može se zaključiti kako je objekt antihreznog pakta, uz ugovor o

possessionem, non habet actionem hypothecariam, sed utitur actione in factum. Prema Glück, F., op. cit., str. 377. Protivnicima teorije o antihrezi kao vrsti zaloga pridružuje se i Gualazzini tvrdeći da nije bilo moguće da je riječ o jednom te istom institutu, polazeći od etimološkog značenja riječi. Prvi oblik raspolaganja posjedovanom stvari, još od antičkih vremena, bilo je plodouživanje (ususfructus). Dakle, antihreza nije mogla biti jednostavno zadržavanje zakonskih kamata kroz ubiranje plodova založene stvari, već je ona morala biti zaključena kao pakt ili zasnovana u postupku koji dopušta korištenje, dakle plodouživanje u punom smislu, stvari dane u zalog, što dovodi do zaključka da antihreza nije zalog. Gualazzini, U., op. cit., str. 529. Također, da bi antihrezu smatrali vrstom zaloga, to jest, vrstom stvarnih prava, morali bi moći tom institutu pripisati osnovne značajke stvarnih prava, a koje obuhvaćaju zaštitu putem actio in rem, ali i apsolutno djelovanje (erga omnes), stvar kao objekt prava, praćenje stvari, sadržavanje negativnog zahtjeva prema trećima da ne smetaju ovlaštenika tog prava, trajan karakter istoga, za što se u dostupnim izvorima ne nalazi dovoljno argumenata.

16 Korištenje založenom stvari smatralo se krađom uporabe (furtum usus), što je za posljedicu imalo infamiju (infamia) počinitelja (u ovom slučaju vjerovnika), to jest, faktički bi značilo ,poslovnu smrt" $\mathrm{s}$ obzirom na to da nakon toga ne bi bio u mogućnosti zaključivati formalističke pravne poslove. Infamija je uzrokovala umanjenje pravne i djelatne sposobnosti, koja se ogledala u gubitku glasačkoga prava, gubitku prava sudjelovanja u sudskom postupku, u nemogućnosti zaključenja braka s osobom iz višega društvenog sloja, u bezvrijednosti ili umanjenoj vrijednosti svjedočkog iskaza i sl. Više o konceptu infamije u rimskom pravu Apsītis, A., Joksts, O., The Concept of Infamy (Infamia) In Roman Law: An Engine for Sustainable Development and Public Security - The Roman Example, Journal of Security \& Sustainability Issues, vol. 3, br. 1/2013; str. 31-41; Chiusi, J. T., 'Fama' and 'infamia' in the Roman Legal System: The Cases of Afrania and Lucretia, u: Judge and Jurist: Essays in Memory of Lord Rodger of Earlsferry (Burrows, A., Johnston, D., Zimmermann, R, ur.), Oxford Scholarship Online, 2013., str. 143165.

17 D.13.7.9.2. (Ulp. 28 ad ed.) Proprie pignus dicimus, quod ad creditorem transit, hypothecam, 
zalogu, također mogla biti i pokretnina i nekretnina. Funkcija ovog pakta ogledala se u ubiranju plodova založene stvari, što je založnom vjerovniku omogućivalo namirenje tražbine na ime kamata pa je takav pakt zapravo služio kao svojevrsni pandan kamatama. ${ }^{18}$ (U prilog tezi o antihreznom paktu ide i razmišljanje Modestina (D.13.7.39.), ${ }^{19}$ u kojem je riječ o primjeru zalaganja stvari uz koje se ugovara pakt o kompenzaciji plodova, odnosno tekst upućuje na sadržaj antihreznog pakta. ${ }^{20}$ )

cum non transit nec possessio ad creditorem. Više u Kieninger, E. M. (ur.), Security Rights in Movable Property in European Private Law, Cambridge University Press, 2004., str. 41.

18 Antihreza je oduvijek neraskidivo povezana s problematikom kamata. U tom se kontekstu postavlja pitanje je li antihreza iznimka od tada nametnutih zakonskih ograničenja kamata koje je postavljalo rimsko pravo. Pravna znanost nije usuglašena oko ovog aspekta, ali mogu se istaknuti dvije vladajuće teorije postavljene na vrlo čvrstim temeljima. Smatra se da antihreza (u širem smislu) ne predstavlja iznimku od zakonskog ograničenja kamatne stope te da viškom ubranih plodova treba namirivati glavnicu tražbine. Međutim, to je samo kada je unaprijed moguće odrediti količinu, tj. vrijednost plodova koji će biti ubrani. U protivnom, kada nije moguće unaprijed odrediti količinu i vrijednost plodova koji će biti ubrani, jer oni ovise o nepredvidivim okolnostima (kao što je primjerice urod plodova vinograda te godine), onda će antihreznom vjerovniku biti dopušteno da sve ubrane plodove zadrži isključivo na ime kamata, zbog rizika koji je preuzeo upuštajući se u ovakvu transakciju. U tom slučaju antihreza će biti iznimka od postavljenog zakonskog ograničenja maksimalne kamatne stope. Zbog maskiranja kamata u postklasici, pod utjecajem kršćanstva, ugovor o zalogu uz antihrezni pakt bio je zabranjivan kao lihvarski ugovor. Više Thomas, P., Antichresis, Hemiolia and the Statutory Limit on Interest in Gerard Noodt's De foenore et usuris, De Jure, vol. 40, br. 1/2007; str. 52-68, Van Niekerk, S. J., et al. (ur.), The Three Book on Interest - bearing Loans and Interest (Foenus et Usurae) by Gerard Noodt, Leiden, Pretoria University Law Press, 2009.

19 Modest. D.13.7.39. Gaius Seius ob pecuniam mutuam fundum suum Lucio Titio pignori dedit: postea pactum inter eos factum est, ut creditor pignus suum in compensationem pecuniae suae certo tempore possideret: verum ante expletum tempus creditor cum suprema sua ordinaret, testamento cavit, ut alter ex filiis suis haberet eum fundum et addidit "quem de Lucio Titio emi”, cum non emisset: hoc testamentum inter ceteros signavit et Gaius Seius, qui fuit debitor. Quaero, an ex hoc quod signavit praeiudicium aliquod sibi fecerit, cum nullum instrumentum venditionis proferatur, sed solum pactum, ut creditor certi temporis fructus caperet. Herennius Modestinus respondit contractui pignoris non obesse, quod debitor testamentum creditoris, in quo se emisse pignus expressit, signasse proponitur. (Gaius Seius gave his land to Lucius Titius as a pledge for money loaned, and afterwards it was agreed between them that the creditor should have possession of the pledge for a certain time, by way of setoff against his money. But, before the time had expired, the creditor, in stating his last wish, provided by his will that one of his sons should have the said tract of land, and added, "which I bought of Lucius Titius," while in fact he had not bought it. Gaius Seius, who was the debtor, along with others signed this will. I ask whether, by the fact that he signed it he prejudiced himself in any way, since no instrument evidencing the sale was produced, but only the agreement that the creditor should be entitled to the crops for a certain time? Herennius Modestinus answered that the contract of pledge was not affected because the debtor had signed the will of the creditor in which he stated that he had purchased the pledge.) Prijevod prema Scott, S. P., The Civil Law, IV, The Enactments of Justinian.The Digest Or Pandects. Book XIII, Cincinnati, 1932.

20 Salmasius tvrdi da prava antihreza nije ovisna o zalogu i ne ovlašćuje vjerovnika na ius distrahendi. Prema njegovom mišljenju za pravu antihrezu karakteristična su dva elementa: posjedovanje nekretnine i ubiranje plodova kako bi se njima kompenzirale kamate zbog uživanja određene svote novca. U tom pogledu razlikuje se od teze koju iznosi Manigk, a koji smatra da se u režimu antihreze plodovima namiruje tražbina, odnosno i glavnica i kamate, a 
Antihrezni pakt dodan ugovoru o zalogu ovlašćivao je založnog vjerovnika na uživanje založene stvari, to jest, na ubiranje plodova založene stvari. Funkcija antihreznog pakta bila je dvostruka te je bila usmjerena i na namirenje kamata ubranim plodovima i na osiguranje tražbine glavnice posjedovanjem nekretnine i kroz založnopravno osiguranje koje je uključivalo i ovlaštenje ius distrahendi, odnosno mogućnost namirenja tražbine realizacijom vrijednosti založene nekretnine. Međutim, treba naglasiti da, unatoč tomu što se takav pakt vrlo često ugovarao uz ručnozaložnu pogodbu, nije bio ograničen jedino na taj ugovor. ${ }^{21}$ Neovisno o tomu što je dominantno stajalište doktrine da se antihrezni pakt dodaje (samo) uz ugovor o zalogu, ${ }^{22}$ činjenica da se neki pakt najčešće dodaje jednom tipu ugovora ne može se upotrijebiti kao argument na temelju kojeg bi se zaključilo da je taj pakt vrsta tog ugovora ili da ga je moguće dodati isključivo tom ugovoru. „Podvrgavanje antihreze zalogu" Manigk ${ }^{23}$ smatra tradicionalnom idejom koja ponajprije proizlazi iz definicije koju je dao Cuiacio, ${ }^{24}$ a za koju Manigk tvrdi da je temeljena isključivo na odlomku Marc. D.13.7.33. (koncept antihreze kao vrste založnog prava) te da su pritom potpuno zanemareni povezani odlomci Digesta, posebice Marc. D.20.1.11.1., koji ćemo analizirati u nastavku rada.

ne samo kamate. Prema Hernandez-Moreno, A., Antichresis o Contrarium Mutuum, Barcelona, Real Academia de Ciencias Economicas e Financieras, 2014., str. 114 et seq.

21 Upravo zato jer funkcija takvog sporazuma nije osiguranje tražbine već ubiranje plodova neke stvari na ime kamata, pactum antichreticum se mogao dodati i drugim ugovorima, kao što ističe Glück, dok suprotno stajalište brani Cuiacio (antichresis est species pignoris...). Prema Gualazzini, U., op. cit., str. 531 i Glück, F., op. cit., str. 374.

22 Teoriju o antihreznom paktu uz ugovor o zalogu podržavaju Pothier, Voet, Glück i Vinnio, iako potonji razlikuje dva oblika antihreze u rimskom pravu: antihrezu koja se ugovarala uz zalog, tj. pactum antichreticum i tzv. čistu antihrezu (anticresi pura). U prilog toj tvrdnji Vinnio ističe kako većina autora drži antihrezu vrstom zaloga ili paktom koji se može ugovoriti samo uz ugovor o zalogu jer se takav oblik antihreze (vezane za zalog) može prepoznati u analiziranom Marcijanovom tekstu D.13.7.33. zbog toga što se ovaj oblik antihreze, kao i založno pravo, štiti putem actio in rem. Prema Hernandez-Moreno, A., op. cit., str. 110, Mirabelli, G., op. cit., str. 10-12, Troplong, T. R., Del pignoramento, del pegno e dell'anticresi, Napoli, Stabilimento tip. e calc. di C. batelli e comp., 1847., str. 214.

23 Manigk, A., Bullettino dell'istituto di Diritto Romano, Roma, Facoltá Giuridica della Roma Universitá, 1911., str. 259-262.

24 V. supra bilj. 15. 


\section{MARC. D.20.1.11.1.}

Marc. D.20.1.11.1. si antichresis facta sit et in fundum aut in aedes aliquis inducatur, eo usque retinet possessionem pignoris loco, donec illi pecunia solvatur, cum in usuras fructus percipiat aut locando aut ipso percipiendo habitandoque: itaque si amiserit possessionem, solet in factum actione uti.
Ako bude zaključen ugovor o antihrezi, pa nekome bude predano zemljište ili zgrade, on sve dotle zadržava posjed na osnovi zaloga dok mu novac ne bude isplaćen, jer on prihode, bilo putem zakupa, bilo putem samostalne obrade odnosno stanovanja, uzima kao kamate; stoga mu, ako izgubi posjed, treba dozvoliti actio in factum.

Analizom Marcijanovog teksta D.20.1.11.1. razvidno je kako se u konkretnom opisanom slučaju tematizira ugovor o antihrezi, kao i o ugovor o zalogu, te da se posjed založnog vjerovnika štiti putem actio in factum. Formulacija dopušta kritiku teorija o antihrezi kao vrsti zaloga i antihrezi kao paktu uz ugovor o zalogu, odnosno otvara prostor za stvaranje nove teorije, one o antihrezi kao samostalnom ugovoru. S obzirom na predviđenu zaštitu posjeda založnog vjerovnika putem actio in factum, odnosno actio praescriptis verbis, umjesto putem actio pigneraticia, kao što je to bio slučaj u drugom (ranije citiranom Marcijanovom odlomku) D.13.7.33., tumačenje ovoga teksta usmjerava prema kategoriji inominatnih ugovora. ${ }^{25}$ Riječ je o ugovorima osmišljenim u kontekstu razvoja društvenih i gospodarskih okolnosti i odnosa koji su doveli do širenja formalnog okvira imenovanih (,nominatnih“/nominiranih) ugovora i priznavanja pravnih učinaka sporazumima koji nisu potpadali pod kategorije postojećih, priznatih, imenovanih ugovora, ${ }^{26}$ već su stoga objedinjeni pod nazivnikom ,inominatnih“ (nova negotia ili contractus incerti). ${ }^{27}$ Ovaj naziv, pod kojim su poznati i danas, nadjenut im je naknadno, kako bi se opisalo i notiralo značenje sporazuma (nudum pactum, nuda pacta, pravno neutuživi sporazum(i)) koji podrazumijevaju neformalno suglasje volja dopuštenog sadržaja - sporazume o činidbi (darelfacere) i (protu)činidbi (darelfacere), a koji postaju utuživi i preuzimaju značajku kontrakta

25 Više u Watson, A., The Evolution of Law: the Roman System of Contracts, Law and History Review, vol. 1, br. 4/1984; str. 19, Burdese, A., Le dottrine del contratto nella giurisprudenza romana, Padova, CEDAM, 2006., Zimmerman, R., The Law of Obligations: Roman Foundations Of The Civilian Tradition, Oxford, Clarendon Press, 1990., str. 508-548, Serafini, F., Institucije rimskog prava, knjiga II, Split, SPLJET, 1896., str. 129-132.

26 Zimmerman, R., op, cit., str. 533.

27 U skupinu inominatnih kontrakata ubrajani su različiti slučajevi obveza bez ili početno bez specifičnog imena (što je postklasični otklon od načela rimskoga klasičnog prava, prema kojem je svaki pojedini obvezni odnos morao imati svoje ime i zaštitu posebnom tužbom). Premda su u kasnijem razvoju pojedini inominatni kontrakti dobili i posebna imena (proprium nomen ( propria apellatio), njihova pojava bila je ne samo veliki korak naprijed u proširenju kruga kontrakata, nego i u probijanju ideje po kojoj bi nakon svake suglasnosti volje koja nije suprotna pravu i moralu trebala slijediti utuživa obveza, cilj do kojeg je došla tek škola prirodnog prava. V. Romac, A., Rimsko pravo, Zagreb, Pravni fakultet u Zagrebu, 2007., str. 374; Petranović, A., Rimske naznake utuživosti sporazuma, Zbornik Pravnog fakulteta Sveučilišta u Rijeci, vol. 20, br. 1/1999; str. 117-128. 
ako je jedna strana ispunila činidbu koju je neformalno obećala, te koji, za razliku od imenovanih ugovora, nisu imali nomen. ${ }^{28}$

Geneza priznavanja inominatnih ugovora bilježi slijed rješenja u zaštiti strane koja je činidbu izvršila, a izostalo je ispunjenje činidbe druge strane, a strana koja je izvršila činidbu dare mogla je tako koristiti pravno sredstvo condictio ob rem dati na temelju pravno razrađenog režima obogaćenja bez osnove, a koja se u Justinijanovom pravu nazivala condictio causa data causa non secuta. ${ }^{29}$ Ako se međutim radilo o ispunjenju činidbe facere (u očekivanju neformalno obećanog ispunjenja činidbe druge strane), u nedostatku pravnog sredstva za traženjem ispunjenja činidbe primjenjuje se (uz dokazano dolozno postupanje) actio doli ${ }^{30}$ i time ostvaruje naknada štete (ne ispunjenje neformalno obećane činidbe). Početkom klasičnog razdoblja pretor je dopustio posebnu tužbu (actio in factum) usmjerenu na ispunjenje protučinidbe. $\mathrm{Na}$ tom uzoru, odobravanjem actio civilis incerti od strane pravnika, smisao i potvrda pretorske zaštite putem actio in factum prepoznaje se u domeni civilnog sustava, ${ }^{31}$ što je potom objedinjeno u režimu actio praescriptis verbis Justinijanova prava. ${ }^{32}$ Naglašavajući u nazivu značenje opisa činjeničnog stanja (praescriptio), actio praescriptis verbis pružala je pravnu zaštitu u svim slučajevima bezimenih ugovora, jednostranog poštovanja sporazuma koji su uključivali činidbu i protučinidbu, a koji nisu potpadali pod tipične i prepoznate imenovane ugovore. ${ }^{33}$

Postavke režima inominatnih ugovora (sadržaj činidbi, nastanak/utuživost, tip tužbe) moguće je prepoznati u analizi Marc. D.20.1.11.1 (cit.): tematizirano postojanje ugovora o antihrezi vezano je za trenutak kada jedna strana prenese vlasništvo određenog iznosa novca (i tako ispuni činidbu koja glasi na dare), čime nastaje obveza druge strane na prijenos posjeda zemljišta ili zgrade (to jest na ispunjenje činidbe facere, odnosno habere licere), a na temelju kojeg se antihreznom vjerovniku pruža zaštita putem actio in factum, što upućuje na zaključak kako je riječ o inominatnom ugovoru do ut facias. ${ }^{34}$

28 Mousourakis, G., Roman Law and the Origins of the Civil Law Tradition, London, Springer, 2015., str. 10.

29 Romac, A., Rimsko..., cit., str. 374., v. bilj. 33.

30 Usp. Paul. D.19.5.5.3. Quod si faciam ut des et posteaquam feci, cessas dare, nulla erit civilis actio, et ideo de dolo dabitur.

31 C.4.64. De rerum permutatione et de praescriptis verbis actione; Dioklecijanova konstitucija C.4.64.6.

32 Prema Justinijanovom pravu mogla se upotrijebiti i condictio causa data causa non secuta, tužba na vraćanje onoga što je dano kada je druga strana svojom krivnjom onemogućila izvršenje protučinidbe ili je u izvršenju svoga dijela obveze upala u zakašnjenje. Romac, A., Rimsko..., cit., str. 375.

33 Mousourakis, G., op. cit., str. 142.

34 Jedan od najistaknutijih zagovornika ove teorije je Vinnio koji ovaj tip antihreze naziva tzv. „čistom antihrezom“ (anticresi pura). Tzv. „čistu“ antihrezu nalazi u tekstu Marcijanova odlomka D.20.1.11.1. i smatra da je riječ o samostalnom ugovoru koji se štiti putem actio in factum i ističe kako je taj oblik antihreze samostalan ugovor kojim vjerovnik stječe plodove loco pignoris, a ne iure pignoris i zaštićen je putem actio in personam. Prema HernandezMoreno, A., op. cit., str. 110; Mirabelli, G., op. cit., str. 10-12, Troplong, T. R., op. cit., str. 214. Treba naglasiti kako romanistika nije prihvatila ovu teoriju o dvojnoj naravi antihreze. Primjer navedenog nalazi se i u argumentaciji koju iznosi Mirabelli, Mirabelli, G., op. cit., str. 11. 
Opciju nastanka tipa ugovora do ut facias (ne ugovora do ut des), određuje ispravna sadržajna / terminološka primjena izraza dare koji u rječniku rimskoga pravnog nazivlja označava prijenos vlasništva, dok se u navedenom analiziranom izvoru radi o jednostavnom odobrenju posjedovanja i korištenja nekom stvari. Riječ je o pravnim poslovima koji se ne odnose na dare/datio, već na jednostavnu traditio, koja se smatra factum..$^{35}$ Tužba koja stoji na raspolaganju strankama je actio in factum preascriptis verbis, ${ }^{36}$ kojom ona ugovorna strana koja je ispunila svoju činidbu iz inominatnog ugovora može zahtijevati od druge strane izvršenje protučinidbe. Ta je tužba, kao actio bona fidei, okrenuta svemu onome što zahtijeva načelo pravičnosti pa tako i predaji kamata ako je, nekim slučajem, stvar prepuštena u antihrezu oduzeta evikcijom. Ako je dug plaćen, onda nema mjesta za condictio sine causa, kao što tvrdi Hoffman, jer u tom slučaju dužnik ima sačuvano netaknuto svoje pravo vlasništva te mu na raspolaganju stoji rei vindicatio (ili actio Publiciana). ${ }^{37}$ Suprotno tomu, da je antihrezni pakt bio priključen ugovoru o zalogu, onda bi postojala osnova za actio pigneraticia, koja bi proizlazila iz ugovora o zalogu. ${ }^{38}$

Iznesena teorija o antihrezi kao inominatnom ugovoru do ut facias doima se smislenom, ali samo polazi li se od pretpostavke da je objekt antihreznog ugovora nekretnina, a ne isključivo njeni plodovi. Međutim, o odgovoru na pitanje je li predmet antihreze nekretnina ili samo njezini plodovi, ovisi i održivost teorija o tomu je li ugovor o antihrezi uzajamna / recipročna uporaba (mutuus usus / contrarium usum) ili, pak, uzajamni / dvostruki zajam (contrarium mutuum).

Uzme li se da je ugovor o antihrezi uzajamna uporaba (novac - nekretnina) nameće se dvojba postoji li u tom slučaju razlika između antihreznog ugovora i zaloga plodonosne stvari. ${ }^{39}$ Ono što se može istaknuti kao razliku je funkcija, s obzirom na to da zalog plodonosne stvari ima funkciju osiguranja tražbine, dok se funkcija antihreznog ugovora ogleda ponajprije kroz značajku dobrovoljnog anticipiranog namirenja. ${ }^{40}$ Prema stajalištu koje zastupa Manigk, u rimskom pravu antihreza je autonomni ugovor koji ima vlastitu fizionomiju, neovisnu o ugovoru o zalogu i obvezi plaćanja kamata, jer služi kao sredstvo namirenja tražbine kroz uživanje neke stvari, a ne kao sredstvo osiguranja tražbine. Dodatno ističe da je takav i etimološki

35 Glück, F., op. cit., Libro XIII.

36 Kao dokaz da je ovdje riječ o actio praescriptis verbis, Glück citira: solet in factum actione uti, čime pobija i mišljenje koje daje Coeccio, a koji želi shvatiti Marcijanov fragment pozivajući se na jedan slučaj u kojem je pakt o antihrezi bio dodan ugovoru o zalogu ex intervallo pa upravo na tom naknadnom ugovaranju antihreze temelji argument zbog kojeg nije bilo mjesta uporabi actio pigneraticia. Međutim, fragment na koji se on poziva, ne bavi se sličnim slučajem jer nema ni spomena o paktu antihreze već je vjerovniku prepušteno uživanje založenog zemljišta, jer je tako dogovoreno, ne na ime kamata, već na ime smanjenja glavnice. Glück, F., op. cit., str. 379.

37 Kontekst (neugrožene) zaštite kviritskog / pretorskog vlasništva.

38 Glück, F., op. cit., str. 379.

39 Više u Romano, S., Appunti sul pegno dei frutti nel diritto romano, Padova, CEDAM, 1931.

40 Funkcija antihreze kao inominatnog ugovora isključivo je usmjerena na cjelokupno namirenje koje se ostvaruje ubiranjem plodova plodonosne nekretnine i koje ne uključuje ius distrahendi, s obzirom na to da nije poveznica sa založnopravnim osiguranjem. 
smisao izraza antihreza koji znači uživanje u zamjenu za neku stvar ${ }^{41} \mathrm{i}$ ističe kako je temeljna karakteristika antihreze namirenje tražbine kroz plodouživanje stvari, što upravo potvrđuje značenje izraza antihreza. ${ }^{42}$ Naime, iz odlomka Marc. D.20.1.11.1. jasno proizlazi da je riječ o antihrezi u kojoj plodovi služe isključivo za namirenje i ne može / ne smije ih se povezati s osiguranjem tražbine, ${ }^{43}$ što potvrđuje da je antihrezu moguće zasnovati neovisno o zalogu, budući da ne postoji logička veza između založnog prava i ploduživanja u svrhu namirenja tražbine.

Analizira li se teza da je ugovor o antihrezi uzajamni zajam ${ }^{44} \mathrm{u}$ kojem jedna strana prenosi vlasništvo određenog iznosa novca, dok druga prenosi posjed plodonosne nekretnine na određeno vremensko razdoblje, susreće se problem definiranih činidbi, $\mathrm{s}$ obzirom na to da činidba u ugovoru o zajmu glasi na dare. Teoriju da antihreza predstavlja uzajamni zajam moguće je poljuljati imajući na umu da su predmet antihreze nepokretne stvari. Naime, ugovor o zajmu je realni ugovor koji nastaje kada zajmodavac preda zajmoprimcu u vlasništvo određenu svotu novca ili drugu zamjenljivu stvar. ${ }^{45}$ Predmetom zajma su prema tomu zamjenljive stvari koje se prenose u vlasništvo zajmoprimca. Ako bi antihrezu shvatili kao uzajamni zajam to bi trebalo značiti (u dimenziji prijenosa vlasništva), da jedna strana prenosi vlasništvo novca, a druga vlasništvo nekretnine, što nije točno jer antihrezni vjerovnik ne stječe vlasništvo stvari koju dobiva u antihrezu i, posebice (ako se fokusiramo na predmet zajma) ne radi se o zamjenljivoj stvari polazi li se od toga da je predmet antihreze nekretnina. Međutim, ako se uzme da predmet antihreze nije nekretnina, nego plodovi te nekretnine, onda je riječ o zamjenljivim stvarima koje mogu biti predmetom zajma. ${ }^{46} \mathrm{U}$ tom bi slučaju ujedno i definirali pravnu prirodu antihreze koja više nikako ne bi bila stvarnopravno osiguranje tražbine, jer ne djeluje na nekretnini, već samo

41 Prema Tedeschi, V., op. cit., str. 1-17.

42 Lovera smatra Manigkovu tezu pretjerano razrađenom, ako se u obzir uzme stvarna važnost antihreze u rimskom pravu. Više u Lovera, M., El contrato de anticresis, Caracas, Universidad Católica Andrès Bello, 1993., str. 5.

43 Riječ je o antihreznom paktu, a ne o antihrezi (kao inominatnom ugovoru).

44 Salmasius smatra da kada se ugovara antihreza, postoje dva zajmoprimca i dva zajmodavca, dva dužnika i dva vjerovnika jer je antihreza uzajamni zajam i da su za pravu antihrezu karakteristične dvije stvari: posjedovanje nekretnine i ubiranje plodova, kako bi se njima kompenzirale kamate zbog uživanja određene svote novca. Salmasius tvrdi da se prava antihreza nalazi u C.4.32.14., kao izvoru u kojem ne postoji niti zalog niti hipoteka, odnosno nikakvo stvarnopravno osiguranje tražbine, već jedino uzajamni zajam. Iz konstrukcije koju zagovara neupitno proizlazi da je antihreza samostalan, glavni ugovor, koji nema niti strukturu hipoteke, a niti ciljeve založnog prava, već se radi o ugovoru o zajmu recipročnog oneroznog i aleatornog karaktera. U tom pogledu razlikuje se od teze koju iznosi Manigk, a koji smatra da se u režimu antihreze plodovima namiruje tražbina, odnosno i glavnica i kamate, a ne samo kamate. Unatoč ovoj razlici i Manigk i Salmasius zastupaju tezu antihreze kao samostalnog ugovora. Prema Hernandez-Moreno, A., op. cit., str. 113-114.

45 V. primjerice Buckland, W. W., A Manual of Roman Law, Cambridge, 1953., str. 272., 273., Pugliese, G, Istituzioni di dirtto romano, Torino, 1991., str. 533 (obligationes re contractae), mutuum str. 534. i dalje, Romac, A., Rimsko..., cit., str. 339 i dalje, Thomas, J. A. C., Textbook of Roman Law, Amsterdam, New York, Oxford, 1976., str. 272 i dalje.

46 Garcia Reyes, A. E., Una nueva oportunidad para la anticresis en ordenamiento juridico guatemalteco, Guatemala, Campus Central, 2010., str. 32, Glück, F., op. cit., str. 374. 
personalno pravo koje djeluje na plodovima te nekretnine. Također, navedeno se sukobljava s kategorizacijom antihreze kao inominatnog ugovora do ut facias, budući da je osnovna karakteristika zajma upravo činidba dare zamjenljivih stvari, što bi onda navodilo na zaključak da je antihreza inominatni ugovor do ut des, a ne (ispravno) do ut facias.

Zagovornici teorije o antihrezi kao vrsti založnog prava i teorije o antihrezi kao paktu uz ugovor o zalogu pokušali su pronaći brojna opravdanja i argumente koji bi poduprli tezu da actio in factum o kojoj govori D.20.1.11.1. (cit.) zapravo podrazumijeva actio pigneraticia te se, između ostalog, izražavala i sumnja u interpolaciju teksta.$^{47}$ Kao jedan od argumenata u prilog tvrdnjama da se u tom slučaju ipak radi o stvarnopravnoj tužbi, koristila se i činjenica da se tematizirani Marcijanov odlomak nalazi u knjizi Digesta koja nosi naslov De pignoribus et hypothecis et qualiter ea contrahantur et de pactis eorum. Međutim, činjenica da tekst Basilica na istom mjestu također spominje in factum actione, potvrdila je kako se nikako ne može smatrati da se ovdje misli na hipotekarnu tužbu. ${ }^{48}$ Salmasius pak tvrdi da je odlomak Marc. D.13.7.33. interpolirao Tribonijan kada je riječ o sintagmi nam cum pignus sit, hoc verbo poterit uti, za što uporište nalazi u odlomku Marc. D.20.1.11.1. Smatra da Marcijan u D.13.7.33. govori o antihrezi kao zemljištu ili nekretnini, dok u D.20.1.11.1. govori o antihrezi kao sporazumu, pa dolazi do zaključka da antihreza znači zemljište, nekretnina, ali i zajam. Slijedom navedenoga zaključuje kako u odlomku Marc. D.20.1.11.1. nema riječi ni o hipoteci, ni o zalogu, već o samostalnoj antihrezi kao ugovoru. Tvrdi da se usporedbom ova dva Marcijanova odlomka može zaključiti kako sintagma nam cum pignus sit, hoc verbo poterit uti nije mogla biti Marcijanova jer u D.20.1.11.1. on vjerovniku koji je izgubio posjed stvari u antihrezi ne daje pravo na actio pigneraticia, kao što bi bio slučaj da je doista riječ o zalaganju stvari, već mu daje isključivo pravo na actio in factum, ${ }^{49}$ što, po njegovom mišljenju, svakako navodi na zaključak da nije riječ o izvornom već o interpoliranom tekstu. ${ }^{50}$

47 Nemoguće je modificirati do potpunog slaganja sve rukopise i izdanja zbirke Digesta zbog brojnih interpolacija kojima su izmijenjeni tekstovi klasičnih pravnika. V. više u primjerice Buckland, W. W., Interpolations in Digest, Yale Law Journal, vol. 33., 1924., str. 344-364., Horvat, M., Rimska pravna povijest, Zagreb, Knjižara Zlatko Streitenberger, 1943., str. 191-196., id. Rimsko pravo, cit., str. 91-92. Jedan od najistaknutijih zagovornika teze o interpolacijama ovog odlomka bio je Noodt koji dolazi do zaključka kako riječi in factum actione u odlomku Marc. D.20.1.11.1. treba zamijeniti riječima hoc actione, jer je to izvorno značenje teksta, pa pod hoc actione onda podrazumijeva hipotekarnu tužbu. Prema Van Niekerk, S. J., et al. (ur.), op. cit., str. 145.

48 Tekst Basilica pri spominjanju actio in factum istovremeno navodi kako nema mjesta actio hypothecaria te bilježi non Serviana sed in factum: non enim proprie pignus est, sed pignoris loco antichresin habet. Prema Glück, F., op. cit., str. 377.

49 Hernandez-Moreno, A., op. cit., str. 114.

50 U Fiorentinskom rukopisu Digesta, kao niti u tekstu Basilica ne postoje tragovi koji bi upućivali na takve riječi. Ne radi se o glosi jer su glosatori u nepoznavanju grčkog jezika izraz antihreza pročitali kao antiphoma. Vidi više Glück, F., op. cit., str. 376. 


\section{PAUL. D.20.2.8.}

Paul.D.20.2.8. Cum debitor gratuita pecunia utatur, potest creditor de fructibus rei sibi pigneratae ad modum legitimum usuras retinere.
Ako se dužnik beskamatno koristi novcem, vjerovnik ima pravo od plodova stvari koja mu je dana u zalog zadržati iznos koji odgovara zakonskoj visini kamata.

Osim što je antihrezni pakt uz ugovor o zalogu bio dodavan suglasnošću stranaka, Paulov odlomak D.20.2.8. navodi na zaključak da je kod osiguranja beskamatnog zajma bila moguća i, tzv. prešutna antihreza (antichresis tacita) ${ }^{51}$ Takva antihreza ovlašćivala bi založnog vjerovnika na plodove založene plodonosne stvari, koji su se smatrali kompenzacijom za zakonske kamate. ${ }^{52}$ Navedena praksa navodno je proizašla iz stajališta kako je i učestalo provođeno i uobičajeno prihvatljivo da nitko ne daje zajam potpuno besplatno, pa ako nije rečeno ništa o kamatama, a založena je plodonosna stvar, da se zapravo podrazumijeva ovlaštenje na ubiranje plodova do visine zakonskih kamata. Iako ova teorija ima puno pobornika, upitna je svrha postojanja sporazumne antihreze ako je prešutna antihreza bila legitimna u tom obliku. Nužno je naglasiti i kako je mutuum rimskog prava primarno bio besplatni pravni posao koji se poduzimao iz prijateljske usluge (i stoga je odvojen od mogućnosti (uzgrednog) stipuliranja kamata), pa se takvim posrednim i prešutnim naplaćivanjem te usluge dovodi u pitanje takav karakter ustanove.

\section{ZAKLJUČNA RAZMATRANJA}

Marcijanovi tekstovi D.13.7.33. i D.20.1.11.1. te Paulov tekst D.20.2.8. temeljni su izvor spoznaja o pojmu i sadržaju instituta antihreze u rimskom pravu. Upravo tako mali broj dostupnih pravnih izvora o antihrezi, kao i vjerojatnost interpolacije istih, doprinio je problemu definiranja instituta, kao i postojanju brojnih više ili manje suprotstavljenih teorija koje su podijelile doktrinu i priskrbile tom institutu brojne epitete negativnog predznaka, stavljajući ga u kontroverzni kontekst lihvarskih i nemoralnih pravnih poslova. Obrada navedenih fragmenata, kao $i$ analiza relevantne pravne doktrine, navodi na zaključak da je većina dvojbi o pojmu, genezi i pravnoj prirodi antihreze $u$ rimskom pravu nastala zbog toga što su se pojmovi antihreza i pactum antichreticum koristili kao sinonimi, iako ima dovoljno podataka koji upućuju da je riječ o dva različita pravna instituta koja karakteriziraju složene $\mathrm{i}$ bitne razlike.

Polazeći od rimskog načela omnis definitio in iure civilis periculosa est, parum est enim ut non subverti posset i interpretacijom rimskoga (klasičnog) pravnog sustava kao primarno sustava akcija (ubi actio ibi ius), kao ključni kriterij provedene analize određene su tužbe, odnosno predviđeni / postojeći sustav pravne zaštite. Upravo zato je proučavanje odlomaka D.13.7.3. i D.20.1.11.1. dovelo do zaključka

51 Retentio usurarum kod besplatnog zajma, tj. forte deposita, vel mutata sine stipulatione usurarum - glosa pecunia D.20.2.8., prema Gualazzini, U., op. cit., str. 531.

52 Romac, A., Rječnik..., cit., str. 59. 
kako je malo vjerojatno da ova dva teksta govore o istom institutu, s obzirom na to da jedan predviđa zaštitu putem actio pigneraticia, dok drugi upućuje na actio in factum. Navedena razlika u pravnoj zaštiti bila je osnova pravnoj doktrini za stvaranje različitih teorija o antihrezi, a nakon podastrte analize moguće je zaključiti kako je rimsko pravo poznavalo pactum antichreticum i antihrezu kao dva različita instituta, drukčijih funkcija i pravne prirode.

Antihrezni pakt, koji je vjerojatno nastao kao iznimka od zabrane korištenja založene stvari i čija je svrha bila namirenje tražbine plodovima te stvari, Marcijan tematizira u D.13.7.33., u konkretnom primjeru povezujući ga s ugovorom o zalogu, te samim time pružajući zaštitu putem actio pigneraticia. S druge strane, u D.20.1.11.1. iznosi primjer samostalne antihreze kao inominatnog ugovora do ut facias, na što ukazuje predviđena zaštita u obliku actio(nes) in factum.

Analizu zaključujemo proučavanjem Paulova teksta D.20.2.8., na kojem se temelji institut prešutne (tacitne) antihreze - institut vezan za zalog plodonosne stvari koji služi kao osiguranje beskamatnog zajma i ujedno omogućuje ubiranje plodova te stvari na ime kamata uobičajenih u tom mjestu, vodeći se idejom da zajmodavac mora imati izvjesne koristi od zajma. Ova je teorija gotovo općeprihvaćena, iako zbog nedostatka sigurnih dokaza o primjeni ovog instituta u praksi, ne može se detaljnije analizirati institut koji svakako dovodi u pitanje temeljnu značajku zajma rimskog prava (mutuum), kao besplatnoga pravnog posla zasnovanog na prijateljskoj usluzi.

\section{LITERATURA}

1. Corpus iuris civilis: Vol. I. Institutiones (recognovit P. Krueger); Digesta (recognovit T. Mommsen, retractavit P. Krueger); Vol. II. Codex Iustinianus (recognovit et retractavit Krueger); Vol. III. Novellae (recognovit R. Schoell, opus Schoellii morte interceptum absolvit G. Kroll); Dublin-Zürich (Weidmann), 1973. (Vol. I.).; 1967. (Vol. II.), 1972. (Vol. III.)

2. Gordon, William M., Robinson, Olivia F. (eds.), The Institutes of Gaius, Cornell (UP), 1988.

3. Mommsen, Theodor, Krüger, Paul, Watson, Alan, (eds.), The Digest of Justinian, (vol. I.-IV.), Pennsylvania, 1985.

4. Mommsen, Theodor, Meyer, Paul, (eds.), Theodosiani libri XVI. cum consuetudinibus Sirmondianis et Leges ad Theodosianum pertinentes, Berolini, 1905.

5. Pothier, Robert G., Le Pandette di Giustiniano, Vol. I; Venezia, Co'tipi di Antonio Bazzarini, 1833.

6. Pothier, Robert G., Le Pandette di Giustiniano, Vol. II; Venezia, Co’tipi di Antonio Bazzarini, 1841.

7. Scott, Samuel P., The Civil Law, IV; The Enactments of Justinian.The Digest Or Pandects, Book XIII, Cincinnati, 1932.

8. Voet, Giovanni, Commento alle Pandette, Venezia, Co'tipi di Antonio Bazzarini, 1837.

1. Alegre de Miguel, Jorge D., La anticresis: funcion e finalidad en el Codigo Civil espanol y en el Codigo Civil de Cataluna, Barcelona, ESADE, Facultat de Derecho, Universitat Ramon Llull, 2013.

2. Apsītis, Allars, Joksts, Osvalds, The Concept of Infamy (Infamia) In Roman Law: An Engine for Sustainable Development and Public Security - The Roman Example, Journal of Security \& Sustainability Issues, vol. 3, br. 1/2013; str. 31-41. 
3. Buckland, William Warwick, A Manual of Roman Law, Cambridge 1953.

4. Buckland, Wiliam Warwick, Interpolations in Digest, Yale Law Journal, vol. 33., 1924.; str. 344-364.

5. Burdese, Alberto, Le dottrine del contratto nella giurisprudenza romana, Padova, CEDAM, 2006.

6. Chiusi, Tiziana J., 'Fama' and 'infamia' in the Roman Legal System: The Cases of Afrania and Lucretia, $\mathrm{u}$ Judge and Jurist: Essays in Memory of Lord Rodger of Earlsferry (ur. Burrows, Andrew, Johnston, David, Zimmermann, Reinhard), Oxford, Oxford Scholarship Online, 2013.

7. Cohen, Boaz, Antichresis in Jewish and Roman Law, Shulsinger Bros. Inc., New York, 1966.

8. Garcia Reyes, Astrid Emilia, Una nueva oportunidad para la anticresis en ordenamiento juridico guatemalteco, Guatemala, Campus Central, 2010.

9. Glück, Federico, Commentario alle Pandette, Libro XX, Milano, Vallardi, 1895.

10. Goebel, Roger J., Reconstructing the Roman Law of Real Security, Tulane Law Review, vol. 36, 1961.; str. 29-66.

11. Gualazzini, Ugo, Anticresi, u: Enciclopedia del diritto, Milano, Giuffre, 1967.

12. Hernandez-Moreno, Alfonso, Antichresis o Contrarium Mutuum, Barcelona, Real Academia de Ciencias Economicas e Financieras, 2014.

13. Horvat, Marijan, Rimska pravna povijest, Zagreb, Knjižara Zlatko Streitenberger, 1943.

14. Horvat, Marijan, Rimsko pravo, Zagreb, Pravni fakultet, 2007.

15. Kieninger, Eva-Maria (ur.), Security Rights in Movable Property in European Private Law, Cambridge, Cambridge University Press, 2004.

16. Lovera, Marco, El contrato de anticresis, Caracas, Universidad Católica Andrès Bello, 1993.

17. Manigk, Alfred, Bullettino dell'istituto di Diritto Romano, Roma, Facoltá Giuridica della Roma Universitá, 1911.

18. Margetić, Lujo, Rimsko pravo, Rijeka, Pravni fakultet, 1998.

19. Mirabelli, Giuseppe, Dell'anticresi, Napoli, Editore Federico Corrado, 1888.

20. Mousourakis, George, Roman Law and the Origins of the Civil Law Tradition, London, Springer, 2015.

21. Petrak, Marko, Koncepcija generalne vindikacijske tužbe u rimskoj pravnoj tradiciji i de lege ferenda, Zbornik Pravnog fakulteta Sveučilišta u Zagrebu, vol. 63, br. 5-6/2013; str. 1037-1062.

22. Petranović, Anamari, Rimske naznake utuživosti sporazuma, Zbornik Pravnog fakulteta Sveučilišta u Rijeci, vol. 20, br. 1/1999; str. 117-128.

23. Pugliese, Giovanni, Istituzioni di diritto romano, Torino, G. Giappichelli, 1991.

24. Randelzhofer, Albrecht Tomuschat Christian (ur.), State responsibility and the individual: reparation in instances of grave violations of human rights, Hague, Kluwer Law International, 1999.

25. Romac, Ante, Rimsko pravo, Zagreb, Pravni fakultet u Zagrebu, 2007.

26. Romac, Ante, Rječnik rimskog prava, Zagreb, Informator, 1975.

27. Romano, Silvio, Appunti sul pegno dei frutti nel diritto romano, Padova, CEDAM, 1931.

28. Serafini, Filippo, Institucije rimskog prava, knjiga II, Split, SPLJET, 1896.

29. Tedeschi, Vittorio, L'Anticresi, Torino, Unione Tipografico - Editrice Torinese, 1952.

30. Thomas, Joseph Anthony Charles, Textbook of Roman Law, Amsterdam, New York, Oxford, 1976.

31. Thomas, Philip, Antichresis, Hemiolia and the Statutory Limit on Interest in Gerard Noodt's De foenore et usuris, De Jure, vol. 40, br. 1/2007; str. 52-68.

32. Troplong, Theodore R., Del pignoramento, del pegno e dell'anticresi, Napoli, Stabilimento tip. e calc. di C. batelli e comp., 1847. 
33. Van Niekerk, S. J., et al. (ur.), The Three Book on Interest - bearing Loans and Interest (Foenus et Usurae) by Gerard Noodt, Leiden, Pretoria University Law Press, 2009.

34. Watson, Alan, The Evolution of Law: the Roman System of Contracts, Law and History Review, vol. 1, br. 4/1984; str. 1-20.

35. Zimmerman, Reinhard, The Law of obligations: Roman Foundations Of The Civilian Tradition, Oxford, Clarendon Press, 1990. 


\title{
Ines Matić* \\ Anamari Petranović**
}

\author{
Summary
}

\section{ANTICHRESIS IN ROMAN LEGAL DOCTRINE}

The paper addresses the problem of definition and content of the antichresis institute approaching the fragments in Justinian's Digest (Marcian's D.13.7.33. and D.20.1.11.1; Paul's D.20.2.8) since their fundamental reference as the only Roman legal sources that explicitly address this institute. The analysis of Marcian's passages D.13.7.33. and D.20.1.11.1, along with relevant accents of legal doctrine, outlines the key elements of antichresis and presents the theories referring legal nature of this institute, suggesting that antichresis and pactum antichreticum are not synonyms (as / has been/ usually presumed), but occur as two different legal institutes thus including essentially different functions, and consequently, different system of legal protection. Segment of the paper focused on the analysis of Paul's text D.20.2.8., introduces the basic features of tacit antichresis (antichresis tacita) correlated with the concept of consensual antichresis.

Keywords: pactum antichreticum, antichresis, tacit antichresis, Roman law, innominate contracts, pledge.

\section{Zussamenfassung}

\section{ANTICHRESIS IN DER RÖMISCHEN RECHTSDOKTRIN}

Dieser Beitrag bearbeitet das Problem der Definierung und der Inhalt der Rechtsfigur der Antichresis bezüglich der Fragmente Markians in den Digesten (D.13.7.33. i D.20.1.11.1.) und des Textes Paulus (D.20.2.8.), weil die genannten Texte die einzigen römischen Rechtsquellen darstellen, welche die Rechtsfigur der Antichresis ausdrücklich thematisieren. Durch die Analyse der Fragmente Markians (D.13.7.33. i D.20.1.11.1.) sowie auch durch die Betonung relevanter Teile der Rechtsdoktrin, unterstreicht man die Hauptmerkmale der Antichresis und stellt die Theorien über die Rechtsnatur dieser Rechtsfigur dar, die darauf hinweisen, dass Antichresis und pactum antichreticum keine Synonyme sind, wie man gewöhnlicherweise vermutet. Es handelt sich dabei um zwei unterschiedliche Rechtsfiguren mit wesentlich unterschiedlichen

* Ines Matić, Ph. D., univ. spec. crim., Postdoctoral student, University of Rijeka, Faculty of Law, imatic@pravri.hr.

** Anamari Petranović, Ph. D., Associate Professor, University of Rijeka, Faculty of Law, anamari. petranovic@pravri.hr. 
Funktionen, was auch zu unterschiedlichen Systemen des Rechtsschutzes führt. Bei der Analyse des Textes Paulus (D.20.2.8.) werden die Hauptmerkmale der stillschweigenden Antichresis (antichresis tacita) in Verbindung mit der Auffassung der einvernehmlichen Antichresis dargestellt.

Schlüsselwörter: pactum antichreticum, Antichresis, antichresis tacita, römisches Recht, innominate Verträge, Pfand.

Riassunto

\section{L'ANTICRESI NELLA DOTTRINA GIURIDICA ROMANISTICA}

Nel lavoro si disamina la difficoltà di definizione ed individuazione del contenuto dell'istituto dell'anticresi alla luce di due frammenti di Marciano contenuti nel Digesto (D.13.7.33. e D.20.1.11.1.) e del testo di Paolo D.20.2.8., posto che proprio tali testi rappresentano le uniche e fondamentali fonti romane che espressamente trattano di questo istituto. Mediante l'analisi dei frammenti di Marciano D.13.7.33. e D.20.1.11.1., come pure delle voci rilevanti nella dottrina giuridica, vengono poste in rilievo le caratteristiche essenziali dell'anticresi e si espongono le teorie sulla natura giuridica di questo istituto, le quali portano a concludere che l'anticresi ed il pactum antichreticum non siano sinonimi, a differenza di quanto sovente si creda; bensì due istituti giuridici differenti dalle funzioni ben diverse e di conseguenza caratterizzati da un diverso sistema di tutela giuridica. Il segmento di lavoro è orientato verso l'analisi del testo di Paolo D.20.2.8., il quale comprova che gli elementi della anticresi tacita (antichresis tacita) sono correlati alla concezione dell'anticresi pattuitiva.

Parole chiave: pactum antichreticum, anticresi, antichresis tacita, diritto romano, contratti innominati, garanzia. 